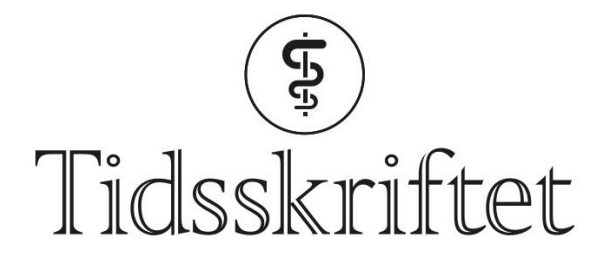

DEN NORSKE LEGEFORENING

\title{
Langt frem til Én innbygger - én journal
}

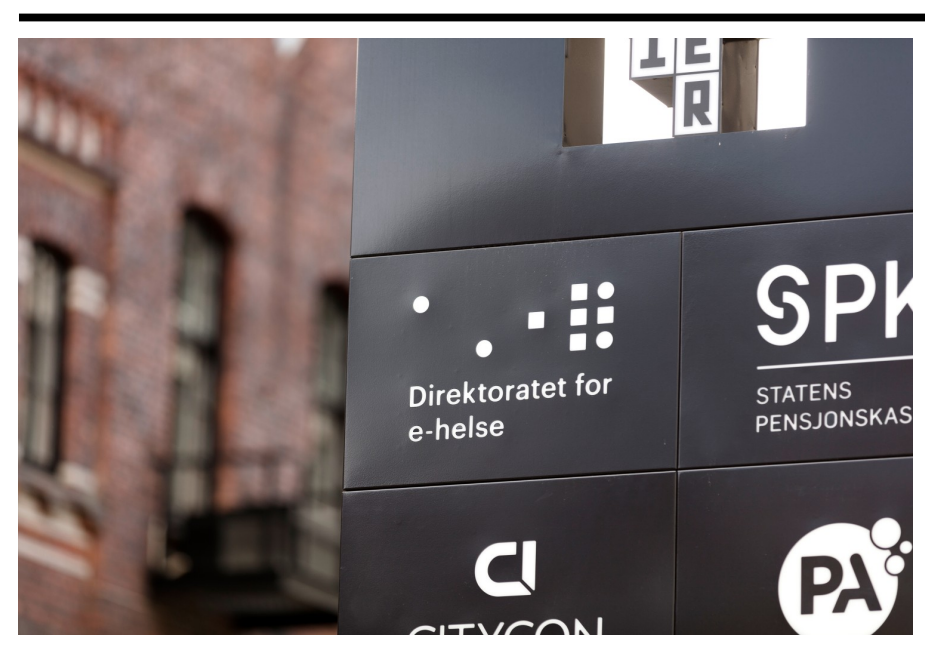

REPORTASJE

EINAR RYVARDEN

E-post: einar.ryvarden@tidsskriftet.no Tidsskriftet

ØYVIND STOPLE SIVERTSEN

Tidsskriftet

Målet om én innbygger - én journal ble satt av regjeringen i 2012. Seks år senere er det fremdeles langt frem.

Merkelappen som ble satt på den første generasjonen IT-systemer i Helse-Norge var ofte «digitalisering av papir». I dette ligger at de ulike helse-IT-systemene har levd i sine egne, isolerte verdener. Viktig og kritisk informasjon ligger spredd i ulike pasientjournalsystemer. En pasient kan ha journaler på flere sykehus. Allmennlegen har sin journal, sykehjemmet har sin og de privatpraktiserende spesialistene har sine.

I 2012 satte regjeringen som mål få å endret dette. Løsningen var visjonen Én innbygger - én journal. Seks år senere har lite skjedd. Når Tidsskriftet spør partene i saken, blir svarene vage og mangelfulle.

Vi spurte landets største sykehuseier, Helse Sør-Øst, om hvordan de ligger an og hvorfor dette ennå ikke er på plass.

- Vi arbeider målrettet mot dette nasjonale målet. Det er Direktoratet for e-helse som har fått i oppdrag å utarbeide et nasjonalt veikart for den samlede gjennomføringen av 
arbeidet, og det er nok de som best kan svare på dine spørsmål, sier konserndirektør Atle Brynestad i Helse $§ ø r-\emptyset$ st i en e-post.

Direktoratet svarer slik på spørsmål om hva som nå er hovedplanen:

- En samlet vurdering av risiko, økonomiske rammer og ulik situasjon i helseregionene har ført til konklusjonen om at det ikke er grunnlag for å planlegge en felles journalløsning på tvers av helseregionene nå, sier Hallvard Lærum, talsperson for Én innbygger - én journal i Direktoratet for e-helse.

\section{Penger og utfordringer}

Hvordan kan det ha seg at aktørene i helsevesenet så langt ikke er blitt enige om en samlet, nasjonal strategi, og hvorfor virker det som om Direktoratet for e-helse har gitt opp?

Å koble sammen IT-systemer som skal dele informasjon kan være komplisert. Et av hindrene har vært mangelen på standardspråk for helsedata. Noe så enkelt som betegnelsen på kalsiumnivået i serum og dets mengdebenevnelse gjøres på ulike måter. Skal systemene kommunisere, må man lage mellomsystemer som oversetter ulike benevnelser, verdier og datatyper til felles standarder.

En annen utfordring i arbeidet med Én innbygger - én journal handler om penger.

Direktoratet for e-helse estimerer i sin utredning fra desember 2015 at ulike løsninger for å gjøre prosjektet til en realitet vil koste over 20 milliarder kroner.

Foreløpig har ikke Stortinget gitt øremerkede midler til helseregionene for at de skal nå målet om denne enhetlige journalen. Hver region disponerer i dag sitt IT-budsjett. Dermed må visjonen om én felles, nasjonal pasientjournal konkurrere med alle andre deler av driften.

Tall fra Direktoratet for e-helse for 2017 forteller at spesialisthelsetjenesten i Norge brukte 8,5 milliarder kroner på IT, mens kommunene brukte 2,4 milliarder. Til sammenligning ble det brukt 6oo millioner kroner på nasjonale løsninger, som e-resept og kjernejournal.

Fremtidens journalsystemer har også andre implikasjoner. Nyere systemer påstås å kunne endre legenes arbeid. De nye systemene inneholder såkalt beslutningsstøtte, som er kunstig intelligens-teknikk som både gir kliniske råd og ferdige beslutninger i stedet for at den enkelte lege selv styrer alt.

\section{Fire eller ett system}

Opprinnelig ønsket Direktoratet for e-helse og Helse- og omsorgsdepartementet ett felles pasientjournalsystem for alle innbyggere i Norge. I stortingsmelding nr. 9 (2012-13) står det: «Regjeringen ønsker derfor å modernisere IKT-plattformen og arbeide for en felles løsning for hele helse- og omsorgssektoren. Det igangsettes et arbeid for å utrede alternative løsninger».

Senere i stortingsmeldingen understreket departementet at «felles målbilder og koordinerte handlingsplaner skal bidra til en mer sammenhengende IKT-utvikling slik at målene om elektronisk samhandling nås».

Men underveis er målet blitt endret. På Lederkonferansen 2018 i februar i år kunne helseminister Bent Høie opplyse om at planen om et nasjonalt IT-system fra én felles leverandør på tvers av helseregionene ikke lenger er aktuelt.

Så da er vi nesten tilbake til start. Hver av helseregionene legger fortsatt sine prioriteringer, budsjetter og tidsrammer for modernisering av journalene. Det er ikke satt noen tidsfrister for når helseregionene må være ferdig med å få sine systemer til å snakke sammen. Og det er ikke lagt noen plan for hvordan hver helseregions ulike pasientjournalsystemer til slutt skal kobles sammen og ende opp med å skape «én innbygger - en journal». 


\section{Ulike valg og tempo}

Situasjonen i de fire helseregionene er høyst forskjellig. Det er Helse Midt-Norge, med base i Trondheim, som satser mest moderne. Dette skyldes at sykehusene i regionen fortsatt bruker et pasientjournalsystem fra 1990-årene og derfor har det mest prekære behovet for en ny løsning. Deres prosjekt Helseplattformen skal ende i anskaffelse av en helt ny, felles pasientjournalløsning - med beslutningsstøtte.

Anskaffelsen i Helse Midt-Norge er blitt prosjektet alle venter på. Ikke bare omfatter det et felles system for alle sykehusene i Midt-Norge, men også for primærhelsetjenesten. Det vil si at fastleger, ambulansetjenesten, sykehjem og andre aktører også skal involveres. Dette vil sikre full informasjonsflyt mellom sykehus og fastleger - men altså bare innen Helse MidtNorge. Etter planen skal det inngås kontrakt med systemleverandør tidlig i 2019, og de første sykehusene og kommunene vil innføre løsningen i 2021.

Det var lenge fire potensielle tilbydere av journalsystemer, men de detaljerte og krevende kravspesifikasjonene gjorde at det våren 2018 kun var de to ledende internasjonale aktørene i markedet, amerikanske Cerner og Epic Systems, igjen i konkurransen. Før sommeren trakk Cerner seg.

De andre tre helseregionene - Vest, Sør- $\emptyset$ st og Nord - har alle EPJ-systemer fra Bodøselskapet DIPS. Regionene bruker imidlertid ikke samme DIPS-versjon og kan derfor ikke koble seg mot hverandre. Blant annet fordi disse DIPS-systemene er nyere enn systemet Helse Midt-Norge vil bytte ut, har de tre helseregionene sagt nei til å erstatte dem. I stedet satser de på å videreutvikle de systemene de allerede har. Første trinn er å koble sammen sykehusene.

Helse $Ø ø r-\emptyset$ st har så langt ikke offentliggjort planer om å koble sykehusene til primærhelsetjenesten. Men konserndirektør Atle Brynestad forteller til Tidsskriftet at helsepersonell etter planen skal få innsyn i pasientjournaler ved andre sykehus i regionen i løpet av 2020.

\section{Utsatte ambisjoner}

Totalt sett tegner dette et bilde av en usikker fremtid for målet om én innbygger - én journal.

- Vi har fokus på å videreutvikle dagens meldingsutveksling, løsninger for dokumentutveksling, videreutvikling av kjernejournal og bedre løsninger for legemiddelhåndtering. Forutsatt finansiering av de større løftene kan primær- og spesialisthelsetjenesten ha vesentlige bedre løsninger og bedre samhandling fra 2022 og utover, sier Hallvard Lærum i Direktoratet for e-helse.

Ser man forbi 2022, står helsesektoren foran to muligheter. Blir Helse Midt-Norges innføring av Helseplattformen-prosjektet en suksess, kan andre helseregioner gjenbruke mye av deres arbeid og erfaringer. Prosjektet har derfor fått status som «regional utprøvingsarena for det nasjonale målbildet».

Det er lett å se fordelene med et felles system for alle Norges 5,3 millioner mennesker. Men det har også noen ulemper. Flere fagpersoner påpeker at et felles, norsk system vil gi leverandøren stor forhandlingsmakt. Om man legger alle eggene i samme kurv, vil svakheter ved systemet ramme hele den norske helsesektoren.

I tillegg kompliseres arbeidet av frykten for prosjekthavari. Store IT-prosjekter feiler ofte, og noen kollapser helt. Stort sett er det organiseringen og styringen av prosjektene, ikke teknologien i seg selv, som feiler.

I Danmark har innføringen av «Sundhedsplatformen» i helseregionen Øst-Danmark blitt kraftig kritisert. Prosjektet ga 2,5 millioner innbyggere et nytt, felles pasientjournalsystem fra leverandøren Epic - den samme som nå står alene igjen som tilbyder til Helse MidtNorge. 
Etter hvert som sykehusene i regionen ble flyttet over på det nye systemet, oppsto det store problemer, og legene hevdet at effektiviteten sank. I en periode mistet blant annet helseregionen oversikt over innkallingen av kreftpasienter. Den danske riksrevisjonen ble satt til å granske prosjektet. Etter oppstyret valgte helseregion Syd-Danmark å utelukke Epic fra sin anbudskonkurranse.

Her i Norge ble det i mai i 2017 avslørt at utenlandske IT-medarbeidere hadde hatt tilgang til helsedata for 2,8 millioner pasienter etter at Helse $\$ \emptyset r-\emptyset$ st gjennom Sykehuspartner hadde satt ut deler av drift og utvikling til Øst-Europa og Asia. I etterkant trakk teknologidirektør i Helse Sør-Øst seg, og deretter ble hele styret i Sykehuspartner byttet ut.

Stadig mer avanserte hackingangrep gir en tilleggsrisiko for alle IT-prosjekter. I januar i år lyktes det hackere å bryte seg inn i sentrale systemer i Helse $§ ø r-\emptyset$ st. Det er fortsatt ikke klart om det ble stjålet pasientdata.

Én innbygger - én journal handler kanskje like mye om politikk som om teknologi.

Skal det nasjonale Direktoratet for e-helse velge, styre og innføre et felles norsk system for pasientinformasjon i alle helseregioner og kommuner? Eller skal hver helseregion, og eventuelt hver kommune, få styre, og kanskje beholde mange av de systemene de bruker $\mathrm{i}$ dag?

Det siste alternativet innebærer at ingen sitter med ansvaret for at journalsystemene på alle nivåer både kan kommunisere med hverandre og faktisk blir koblet sammen for å skape det som vil fremstå som et felles IT-system.

\section{Behovet}

Nytten av én journal er størst for de med sammensatte lidelser. Lege i spesialisering Odd Bjørn Salte tror beslutningstakerne ikke har forstått behovet.

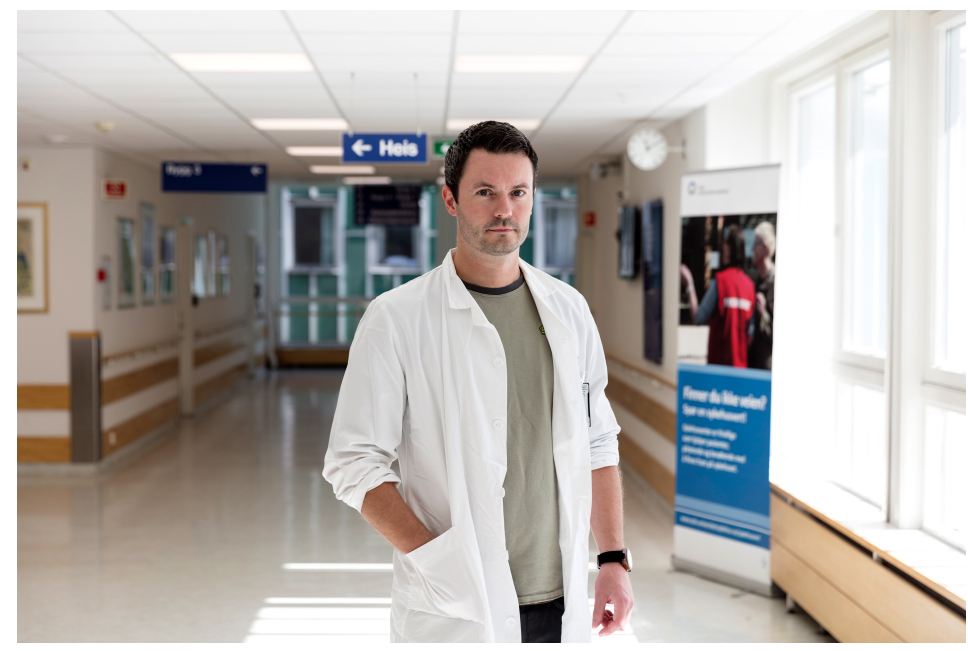

- For de unge og friske går det jo stort sett greit. Det er når vi møter de med kronisk sykdom at vi oppfatter det som håpløst. De som har vart syke siden 1970-årene har fyldige journaler.

Informasjonen ligger spredt, og vi finner ikke opplysningene vi trenger, sier Salte ved Kirurgisk avdeling ved Oslo universitetssykehus, Ullevål.

Han mener et felles, nasjonalt pasientjournalsystem ville gått rett inn i hverdagen til norske leger og gjort den bedre.

- I en akuttsituasjon trenger vi å få full oversikt raskt. Vi bruker mye tid på å lete etter 
opplysninger. Jeg klarer ikke å skjønne hvorfor det ser ut til å ta ti år å få dette på plass. Jeg tror nok ikke man forstår behovet. Det er få klinikere som jobber med IT-systemer. Det er få som vil det, fordi man da må gå ut av klinisk arbeid, sier Salte.

Han er skuffet over utviklingen de siste årene.

- Jeg merker ikke noe til at det finnes et e-helsedirektorat, og jeg vil si at jeg er over middels interessert i feltet. Jeg har en følelse av at innspillene vi kommer med ikke blir hørt og at det ikke blir gjort noe med det vi melder inn av behov.

- Hvorfor?

- Det virker å være en underliggende mistillit. Folkene fra IT-bransjen stoler ikke på legene og tror de kun er ute etter å verne om sine egne interesser. I tillegg virker det å være enormt mange som styrer med dette.

\section{Beslutningsstøtte}

De nye pasientjournalsystemene inneholder en stor nyhet: Beslutningsstøtte. Innført i stor skala vil dette være et ekte paradigmeskifte for mange av landets leger.

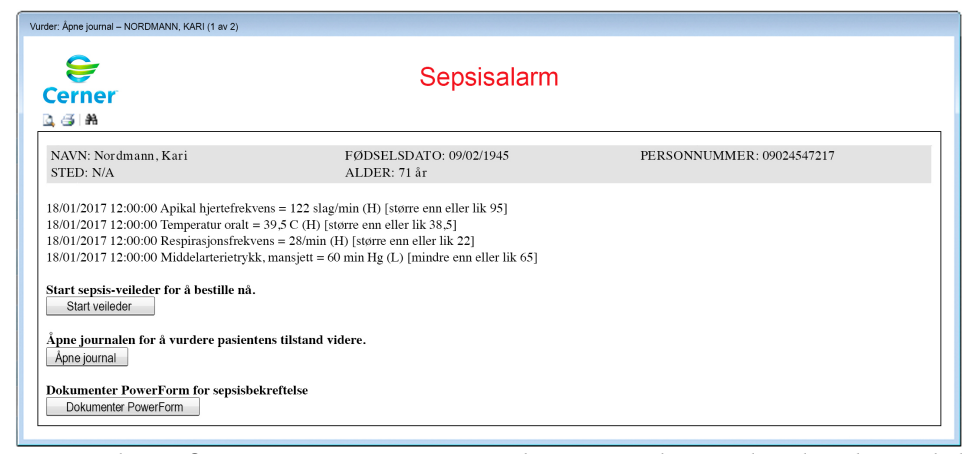

Sepsisalarm fra Cerners system. Gjenskapt etter lavoppløselig skjermbilde fra leverandøren.

Grovt sagt er dagens pasientjournalsystemer passive, historiske arkiv for hva som har skjedd med pasienten. Beslutningsstøttesystemer jobber i stedet i sanntid og serverer både advarsler og råd.

Slik fungerer det: Etter hvert som helsepersonell legger inn informasjon om en pasient, vil beslutningsstøttesystemet analysere alt og servere alarmer, kontrollspørsmål, pålegg, råd og anbefalinger om diagnostisering, prøver, medikamenter, annen behandling og oppfølging.

Et konkret eksempel er beslutningsstøttesystemer for å forutse sepsis. Enklere beslutningsstøttesystemer i helsesektoren analyserer bare kliniske og demografiske data som feber, CRP og alder. Men i et eksperiment på legevakten ved det israelske sykehuset BIDMC la man til at beslutningsstøttesystemet også skulle følge med på om det dukket opp utvalgte nøkkelord i notatene som sykepleierne og legene la inn. Dette ga signifikant økning i treffsikkerheten til systemets evne til å slå alarm om kommende sepsis, ble det hevdet i en artikkel i PLoS One i april 2017.

Målet med beslutningsstøtte er både høyere og jevnere kvalitet i behandlingen. Visjonen er at slike systemer i fremtiden vil endre mange legers hverdag. Fra å måtte vite, huske og styre alt selv kan legen nå i større grad vurdere forslagene som systemene serverer - og adlyde ordrene de gir med mindre de kan begrunne hvorfor disse ikke skal følges.

Systemene fungerer ved bruk av det mange kaller kunstig intelligens, mer presist teknikken 
som kalles maskinlæring. Maskinlæring er enkelt forklart spesiell programvare som analyserer store mengder pasientdata og regner ut sammenhenger mellom faktorer som statistiske sannsynligheter. I motsetning regner vanlige IT-systemer bare 1 eller o, ja eller nei. Når man så begynner å legge inn data om en ny pasient, for eksempel alder, kjønn, måleverdier og symptomer, vil systemet finne så like tilfeller som mulig i sin kunnskapsbank og komme med forslag basert på sannsynligheter.

Ofte fremstilles kunstig intelligens som en generell teknikk man kan skru på og som kan gi nesten feilfrie sorteringer, forutsigelser og andre typer svar. Dette etterfølges gjerne av påstander om at hele yrkesgrupper, for eksempel leger, snart vil forsvinne. Sannheten er at kunstig intelligens er et verktøy som må tilpasses, justeres og trenes av fagfolk for hver oppgave man skal gjøre. Og her ligger en annen utfordring: Hvem skal tilpasse systemene? Skal utenlandske leverandører levere ferdig tilpassede systemer eller må for eksempel hver helseregion skape rutiner, justere og lære opp sine systemer?

Publisert: 3. september 2018. Tidsskr Nor Legeforen. DOI: 10.4045/tidsskr.18.0519

(C) Tidsskrift for Den norske legeforening 2020. Lastet ned fra tidsskriftet.no 